\title{
PREFIXOS NA CONTRAMÃO
}

"...o futuro parecia vir a ser muito melhor.

Pelo menos of futuro tinha a vantagem de

não ser o presente..."

(Clarice Lispector)

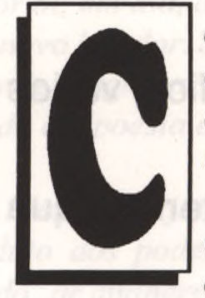

edo, muito cedo! Na verdade, madrugada ainda. E lá vai ele. Endereço? Quem dera fosse aquele que o inconsciente guia - o da rotina de um emprego estável! Mas não é. A data da última baixa em sua carteira de trabalho insiste em permanecer como anotação final. Por isso, antena ligada durante o trajeto. Se necessário, uma informação a mais, afinal é preciso chegar cedo, quanto antes melhor.

Sabe, é verdade, que ordem de chegada na fila não é quesito que conta na hora da seleção, mas evitar um chá de calçada é fato que já não pode deixar de ser computado como um ganho. Elá vem, apressado, o desempregado.

Logo a seguir outro personagem desponta, sem dúvida seu parente mais próximo - o subempregado.

Quando o dia vê-se acordado, juntos, lá estão eles repletando calçadas e transformando em verdadeiros estreitos os chamados Largos das cidades.

Na realidade, são velhos conhecidos nossos, cunhados sob as mais diversas denominaçães: marreteiros, desempregados, autônomos, subempregados, ambulantes, trabalhadores do setor informal.., enfim, um verdadeiro exército de gente.

Mas que universo é este que aparentemente anda na contramão?

Travessia buscou, ora através de um olhar muito próximo, onde personagens ganham nome e têm idade, ora através de um olhar que requer certo distanciamento, dar um mergulho nesta realidade. O resultado encontra-se agora às mãos do leitor que terá oportunidade de tomar contato com as diversas contribuições aqui apresentadas, as quais oferecem:

- o rosto e o dia-a-dia barulhento e aparentemente caótico dos ambulantes do Largo 13 de Maio, da cidade de São Paulo;

- a fala das ex-funcionárias da CALFAT - mulheres que ao retornarem de suas férias coletivas encontraram a empresa fechada e resolveram acampar na calçada;

- a descrição do comportamento do mercado de trabalho na Grande São Paulo nos anos mais recentes, onde se constata a elevação da taxa de desemprego e a alteração no perfil da população ocupada como contrafaces da estratégia empresarial diante da retração da economia;

- as reais intenções dos que promovem as Frentes de Trabalho para os desocupados "da seca" no Nordeste controle e disciplinarização da mão-de-obra;

- uma revisão de estudos dirigidos sobre os efeitos psicossociais e psicopatológicos nos desempregados, quer em nivel de paises desenvolvidos, quer em nivel de América Latina e do Brasil em particular, sobressaindo-se como uma das preocupações a questão do desemprego prolongado;

- uma revisão dos estudos, também em nivel de América Latina, dedicados ao trabalho informal, buscando sobretudo avançar na compreensão do fenômeno, definindo-o, no caso especifico do Brasil, como um processo de "informalização" e "ilegalização" do mercado de trabalho, que longe de se constituir em algo paralelo ao setor formal-legal da economia, está a ele intimamente articulado, subordinadamente;

- uma experiência educativa em curso na cidade de Porto Alegre/RS, envolvendo de um lado, um grupo de mulheres recicladoras de lixo, e, de outro, o Estado, representado pelo poder municipal, experiência que possibilita pontualizar avanços no processo de educação popular; destacar uma presença nova do Estado em termos de politicas públicas e, a partir de uma micro experiência, assinalar concretamente para a possibilidade de um novo modelo de desenvolvimento.

“...sempre há um melhor para o ruim". (Clarice Lispector)

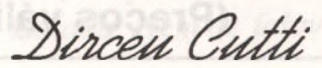

